\title{
THE ANTS OF THE GENUS LASIUS FABRICIUS (HYMENOPTERA, FORMICIDAE) FROM THE LATE EOCENE EUROPEAN AMBERS
}

\author{
G. M. Dlussky \\ Biological Faculty of the Moscow State University, Vorob'evy gory, \\ Moscow, 119899, Russia \\ E-mail: dlusskye@mail.ru
}

Received 12 April 2011

Accepted 21 April 2011

The Ants of the Genus Lasius (Hymenoptera, Formicidae) from Late Eocene European Ambers. Dlussky G. M. - Finds of the genus Lasius Fabricius in the Baltic, Bitterfeldian, Rovno, and Scandinavian Ambers (Late Eocene) are revised. Neotypes of L. pumilus Mayr, 1868 and L. punctulatus Mayr, 1868 are designated. A key to workers and gynes of Lasius species from the Late Eocene European ambers is compiled. All Lasius species from these ambers belong to the subgenus Lasius s. str. L. schiefferdeckeri Mayr, 1868 is one of most abundant ant species in the Late Eocene European ambers: it consists 15.2-19.5\% of all ant specimens in Baltic Amber, 24.5\% in Bitterfeldian Amber, 23.8\% in Rovno Amber, and 23.6\% in Scandinavian Amber of the examined collections. Based on the features of fossilization of this species, it is possible to assume that at least in part it constructed arboreal nests and made roads to aphids' colonies. The list of nine ant species found in syninclusions with $L$. schiefferdeckeri is provided.

Key words: Hymenoptera, Formicidae, Lasius, ants, Key, Baltic amber, Bitterfeldian amber, Rovno amber, Scandinavian amber, Late Eocene.

Муравьи рода Lasius (Нуmenoptera, Formicidae) из позднеэоценовых янтарей Европы. Длусский Г. М. - Ревизованы находки рода Lasius Fabricius из балтийского, биттерфельдского, ровенского и скандинавского янтарей (поздний эоцен). Обозначены неотипы L. pumilus Mayr, 1868 и L. punctulatus Mayr, 1868. Приведена таблица для определения видов Lasius позднеэоценовых янтарей Европы по рабочим и самкам. Все виды из позднеэоценовых янтарей Европы относятся к подроду Lasius s. str. Одним из самых массовых видов муравьев янтарей является L. schiefferdeckeri Mayr, 1868. В изученных репрезентативных коллекциях балтийского янтаря его особи составляли $15,2-19,5 \%$, биттерфельдского $-24,5 \%$, ровенского $-23,8 \%$ и скандинавского $-23,6 \%$. Основываясь на особенностях захоронения этого вида, можно предполагать, что его гнезда, по крайней мере, частично располагались на деревьях и что муравьи делали на стволах дороги к колониям тлей. Приведен список из 9 видов муравьев, обнаруженных в сининклюзах с L. schiefferdeckeri.

Кл юче вы е с лов ва: Hymenoptera, Formicidae, Lasius, муравьи, определитель, балтийский янтарь, биттерфельдский янтарь, скандинавский янтарь, поздний эоцен.

\section{Introduction}

The genus Lasius Fabricius contains 99 extant species, distributed in Holarctic Region (Bolton et al., 2006, with alterations). Its species are one of the most common ants in the forests and meadows ecosystems where they play a critical role in soil constructions and the pest control. Some species of the genus can cause harm, tending aphids injuring crop plants.

There are also known 15 fossil species definitely belonging to the genus Lasius: L. nemorivagus Wheeler, 1915, L. pumilus Mayr, 1868, L. punctulatus Mayr, 1868, and L. schiefferdeckeri Mayr, 1868 from Baltic Amber (Late Eocene), L. peritulus (Cockerell, 1927) from Oligocene deposits of the USA (Florissant); L. epicentrus Theobald, 1937 from Oligocene deposits of France (Aix-en-Provence), L. tertiarius G. Zalessky, 1949 and $L$. vetulus Dlussky, 1981 from Miocene deposits of Russia; L. inflatus (Zhang, 1989), L. mordicus Zhang, 1989, L. truncatus Zhang, 1989 and L. validus Zhang, 1989 from Miocene deposits of China (Shanwang); L. oblongus 
Assmann, 1870, L. chambonensis Piton et Theobald, 1935 and L. crispus Piton et Theobald, 1935 from Miocene or Pliocene deposits of France and Germany.

Leucotaphus gurnetensis (Cockerell, 1915) from the Oligocene deposits of Great Britain (Bembridge) also might belong to the genus Lasius (Donisthorpe, 1920). The actual number of fossil species after revision of the Miocene species most probably will be much lesser. First, the quality of the majority of the Miocene prints is not sufficient to recognize many diagnostic features of the genus Lasius, or they should be transferred into the formal genus Leucotaphus Donisthorpe, 1920.

Mayr (1867) pointed out that some species, originally described by Heer (1849) from the Miocene deposits of Radoboj (Croatia) and Oeningen (Germany) in the genus Formica, in fact belong to the genus Lasius. However, Mayr examined only numerous samples determined by Heer, but did not see the type specimens. Nevertheless, he found that most of the prints, determined by Heer as the same species, belonged to different genera or even to different subfamilies. Unfortunately, Mayr did not propose formal synonymy, and at present it is impossible to say what Heer's species really belong to the genus Lasius. Definitive judgment about generic affiliation of these species can be made only after revision of the type specimens from the collection of Heer, deposited in the Landesmuseum Joanneum Graz, Austria.

The first proper revision of the ants of the Baltic Amber was made Mayr (1868). Fifty species have been described in this paper, including four Lasius ones: L. schiefferdeckeri, L. pumilus, L. edentatus, and L. punctulatus. Nevertheless, these descriptions are largely outdated, and the drawings are not accurate enough; moreover, the drawings were based not on the concrete specimens, but are rather a conventional reconstruction. Wheeler (1915) in his classic monograph on the ants of Baltic Amber only described one more new Lasius species, L. nemorivagus, but, unfortunately, he did not revise the previously described species of this genus. Wheeler only listed the studied specimens, made some general remarks and draw lone L. schiefferdeckeri.

In 1955, Wilson published a taxonomic revision of the genus Lasius of the World, where he also redescribed the Baltic Amber species. At that time he examined only 11 workers and three males of $L$. schiefferdeckeri, and three workers of L. pumilus from the collection of W. Haren; this material was determined by Wheeler and stored in the Museum of Comparative Zoology at Harvard University. Despite this he synonymised the name L. edentatus with L. schiefferdeckeri, and L. punctulatus - with L. pumilus. Since then, any revision of Lasius of the Late Eocene ambers was not published, except for reports of finding of L. schiefferdeckeri in the Rovno Amber (Dlussky, Perkovsky, 2002), and papers by Perkovsky (2007, 2008) on finding this species with aphids in the Rovno and Bitterfeldian Amber.

In recent years I have examined the very rich collections of ants of the Baltic (Kaliningrad Region of Russia, and Poland), Bitterfeld (Germany), Rovno (Ukraine) and Scandinavian (Denmark) Ambers, including all accessible specimens determined by Wheeler. The study of this material allowed me to redescribe and to make drawings of most species of Lasius, described from the Late Eocene ambers of Europe, and to compile a key for their identification.

\section{Material and methods}

The collections from the following Institutions and Museums were investigated: Paleontological Institute of the Russian Academy of Sciences, Moscow, Russia (PIN) - Baltic Amber; Shmalhausen Institute of Zoology of the National Academy of Sciences of Ukraine, Kiev, Ukraine (SIZK) - Rovno Amber; Muzeum Ziemi of the Polish Academy of Sciences, Warsaw, Poland (MZ PAN) - Baltic Amber; The Natural History Museum, London, UK (BMNH) - Baltic Amber; Geowissenschaftlicher Zentrum der Georg-August-Universitat Gottingen, Germany (GZG.BST) - Baltic Amber; this collection is a part of the old collection, previously preserved in the Geological Institute of Königsberg and investigated by Wheeler 1915)1; Humboldt Museum, Berlin, Germany (HM) - Bitterfeldian Amber; Zoological Museum of University of Copenhagen, Denmark (ZMUC) - Scandinavian and Baltic Ambers; private collection of Manfred Kutscher, Sassnitz, Rugen, Germany (MKC), bequeathed tot the Paleontological Institute of Gettingen University, Germany (GZG.BST) - Bitterfeldian Amber.

Images were made by the following procedure. Initially, we made digital photos of inclusions under a microscope Leica S60E with a digital camera DCM500. Then, looking at the sample under a binocular microscope, we traced the image with a pencil. Those images were scanned using the flatbed scanner, the images were imported into the program CorelDraw 9 and made the final images. The solid lines on figures show the boundaries of the visible tergites and sutures. The dotted line shows the boundaries between tergites and sutures that are not visible in a specimen. The dots show the folds and sharp creases that do not coincide with sutures.

All figures represent the exact images of actual specimens at the same position as they are fossilized in amber. Only distinctly seen standing hairs in the specimen in the given position in figure are shown (usually, the hairs on the body contour). Measurements were taken in the standard positions: the mesosoma exactly in profile, the head in full face view. Since in many cases the specimens could not be visible in the proper positions, only parts of the standard measurements were usually made.

${ }^{1}$ In the lists of the examined specimens from the former Königsberg's collection I included both new code numbers (with an index of GZG.BST) and old ones of the Königsberg's collection (in brackets) when these specimens are mentioned first, but for the further mentions I used only the first (new) number. 
Subfamily FORMICINAE Latreille, 1802

Genus Lasius Fabricius, 1804

Lasius schiefferdeckeri Mayr, 1868

Lasius schiefferdeckeri Mayr, 1868: 44, tab. I, fig. 2, tab. II, fig. 27-32 (worker, gyne, male), Baltic Amber, Late Eocene; Dalla Torre, 1893: 191; Andrŭ, 1895: 82; Handlirsch, 1907: 861; Wheeler, 1915: 120, fig. 58 (part.); Wilson, 1955: 52-56; Burnham, 1978: 114; Ponomarenko, Schultz, 1988: 35; Bolton, 1995: 225; Длусский, 1997: 59, fig. 3b; Длусский, Перковский, 2002: 12.

Lasius edentatus Mayr, 1868: 46 (male), Baltic Amber, late Eocene; Dalla Torre, 1893: 183; Andrŭ, 1895: 82; Handlirsch, 1907: 861; Wheeler, 1915: 124; Burnham, 1978: 114; Длусский, 1997: 59; synonymy by Wilson, 1955: 52, confirmed here.

Lasius punctulatus: Wheeler, 1915: 123 (part.), nec Mayr, 1868: 46.

Material. Syntypes GZG.BST N 04221 (3727-IV-75), 04222 (410-IV-55), 04223 (407-IV-54) (workers). Non-type material: Baltic Amber - 490 workers, 10 gynes, 7 males, among them: GZG.BST - 219 workers, 8 gynes, 4 males, including 128 workers, 3 gynes and 3 males determined by Wheeler as L. schiefferdeckeri, and 3 gynes, determined by him as L. punctulatus; PIN - 67 workers, 1 gyne, 2 males; MZ - 179 workers; BMNH - 14 workers (including one specimen determined by Emery as L. schiefferdeckeri) and one male; Bitterfeldian Amber: HM - 150 workers, 3 gynes, 4 males, 1 pupa; GZG.BST (MKC) - 62 workers, 1gyne, 1 male, 10 larvae, 1 pupa; Rovno Amber: SIZK - 156 workers, 2 males, 1 larva, 3 pupae. Scandinavian Amber: ZMUC - 64 workers, 3 males.

\section{Redescription}

Worke r (fig. 1, 1-7). Body length $2.5-4.2 \mathrm{~mm}$. Head trapezoidal, narrowed anteriorly, with rounded occipital corners and straight or slightly concave occipital margin. Eyes oval, comparatively well developed, shifted somewhat posteriorly so that length of gena more than maximum diameter of eyes. Ocelli present, at least in the most of major workers. Frontal triangle separated form rest of head by sutures. Frontal carinae feebly curved, reaching to level of lower margin of eyes. Anterior clypeal margin evenly convex. Clypeus (seen in profile) gradually convex. Scape surpassing occipital margin. Funicular segments somewhat widened to the apex, but apical club not developed. Length of 2nd to 4th funicular segments more than width. Masticatory margin of mandible with six teeth. Palp formula 6, 4. Maxillary palp long, reaching occipital foramen. Mesosoma with promesonotal and metanotal sutures, mesopleural suture absent. Dorsal surface of promesonotum (seen in profile) forming regular arch, promesonotal groove very weak. Propodeum (seen in profile) angled, its posterior (declivous) surface more than twice as long as dorsal one. Petiolar scale (seen in front or from behind) wide, with almost parallel sides, rounded dorso-lateral corners and either weakly convex or weakly concave dorsal margin. Body finely punctated, appears somewhat shiny. Decumbent hairs on whole body very thin and short, thin and short decumbent hairs present on whole body. Head, mesosoma and gaster, as a rule, with standing hairs. Scape, femora and tibiae without erect or suberect hairs.

Gyne (fig. 2, 1-2). Body length 4-6 mm. Head somewhat narrower than mesosoma, trapezoidal, narrowed anteriorly, with rounded occipital corners and straight or slightly concave occipital margin; 1.1-1.2 times as long as wide. Ocelli forming obtuse triangle. Eyes of moderate size, shifted somewhat posteriorly; length of gena usually more than maximum diameter of eyes, but occasionally equal to or even somewhat less $(<1.3$ times $)$ than diameter of eyes. In other features head as in workers. Dorsal surface of scutum flat, scutum strongly curved down anteriorly, but not overhanging pronotum. Scutellum feebly convex. Propodeum (seen in profile) more or less evenly rounded. Dorsal margin of petiolar scale (seen in front or from behind) straight or weakly concave. Body finely punctated, of shiny appearance. Mandibles with longitudinal striation. Decumbent pubescence on head and mesosoma either completely absent, or only very short appressed hairs present, their length less or equal to the distance between them. Gastral tergites with denser pubescence, but appressed hairs also very short. Standing hairs either absent, or at most 

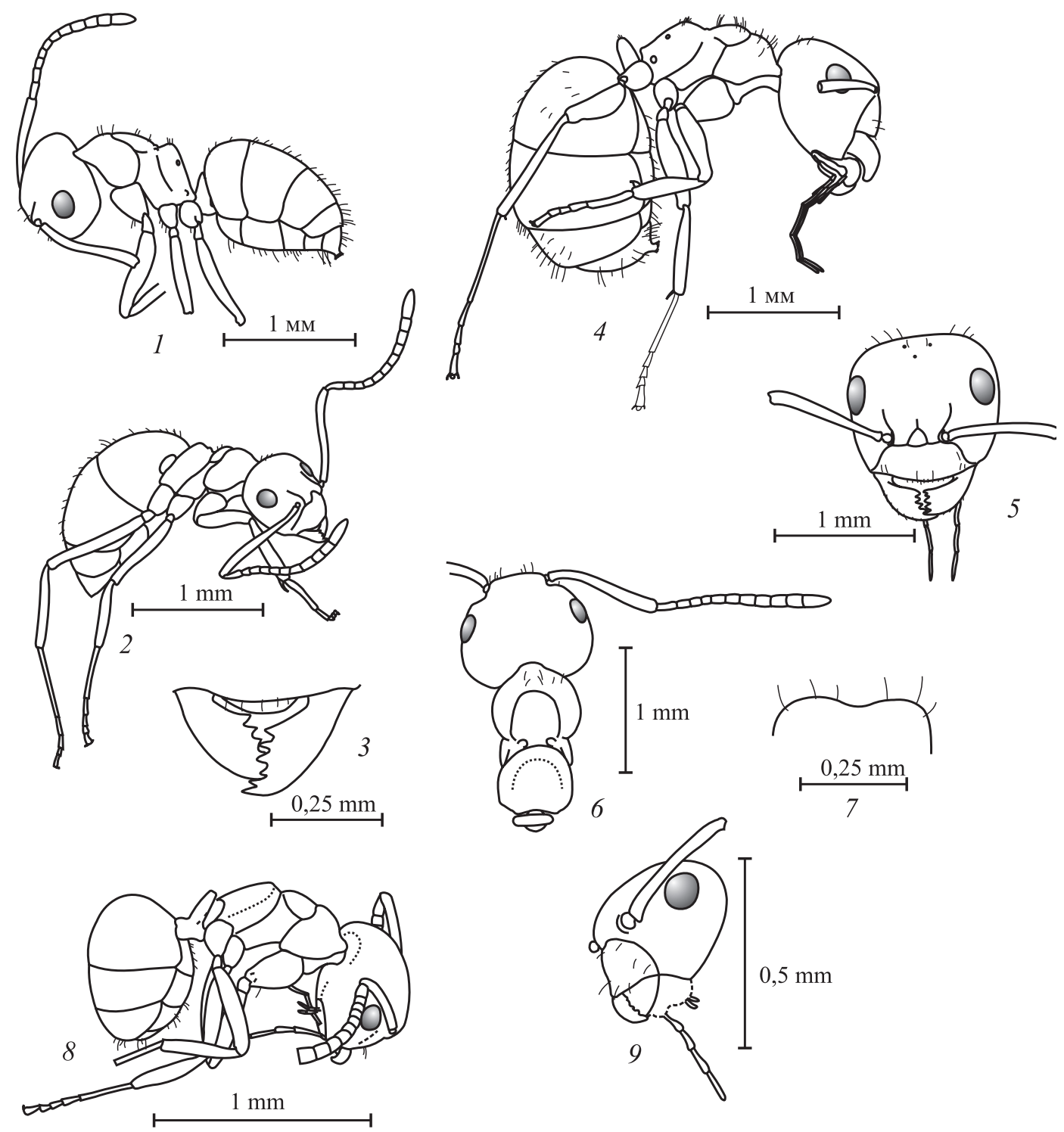

Fig. 1. Workers of Lasius of Late Eocene ambers. L. schiefferdeckeri (1-7): 1 - ex. GZG.BST N 04211, general view of the inclusion; $2-$ ex. PIN N 964/474, general view of the inclusion; 3 - ex. GZG.BST N 04265, mandibles and anterior margin of the clypeus; 4-7 - ex. SIZK N K-5267: 4 - general view of the inclusion; 5 - head in full face view; 6 - mesosoma from above and antenna; 7 - upper margin of the scale. $L$. pumilus, neotype MZ N 2089: general view of the inclusion; (8) and head (9).

Рис.1. Рабочие особи Lasius позднеэоценовых янтарей. L. schiefferdeckeri (1-7): 1 - экз. GZG.BST N 04211, общий вид инклюза; 2 - экз. ПИН N 964/474, общий вид инклюза; 3 - экз. GZG.BST N 04265, мандибулы и передний край клипеуса; 4-7 - экз. ИЗШК N K-5267: 4 - общий вид инклюза; 5 голова сверху; 6- мезосома сверху и антенна; 7 - верхний край чешуйки. Lasius pumilus, неотип MZ N 2089: общий вид инклюза (8) и голова (9).

solitary hairs present on clypeus, ocellar region, on frons, and on scutum. Scape, femora and tibiae always without erect or suberect hairs. Forewing with two closed radial (1 $+2 \mathrm{r}$ and $3 \mathrm{r})$ and mediocubital (= discoidal) $(\mathrm{mcu})$ cells. Radiomedial ( $\mathrm{rm})$ cell absent. Mediocubital cell relatively large. Vein sections 5RS and $4 \mathrm{M}$ with joint start (rs-m lost).

Male (fig. 3, 1-2). Body length 2.5-3.5 mm. Head width subequal to width of scutum. Head slightly narrowed anteriorly, with broadly rounded occipital corners and convex occipital margin. Clypeus (seen in profile) convex; its anterior margin (seen from above) 


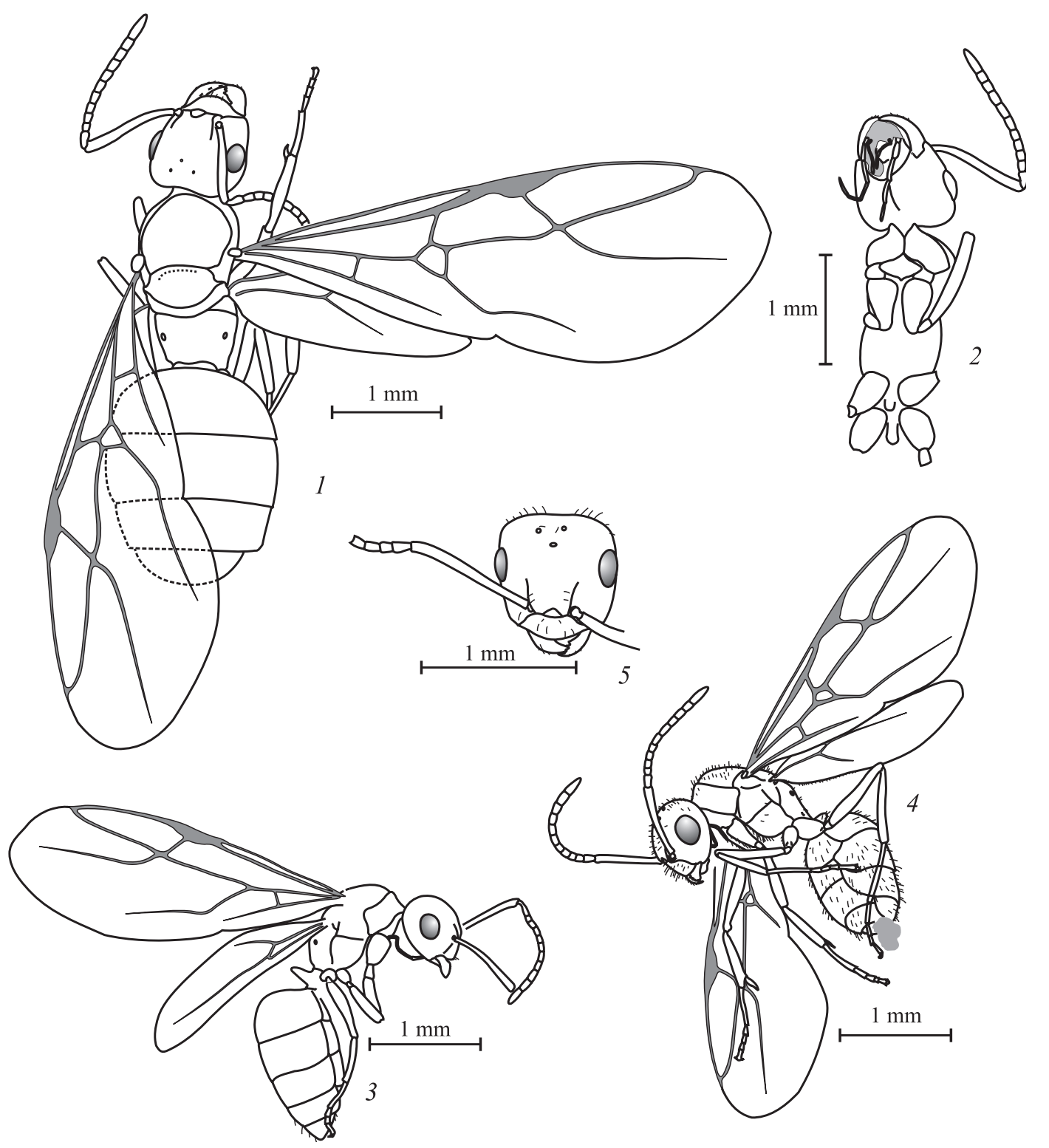

Fig. 2. Gynes of Lasius of Late Eocene ambers. L. schiefferdeckeri (1-2): ex. GZG.BST N 04188, general view of the inclusion from above (1) and from below (2). Lasius pumilus (3): ex. GZG.BST N 04099, general view of the inclusion. Lasius punctulatus : 4 - neotype, PIN N 964/475, general view of the inclusion; 5 - ex. BMNH $\mathrm{N}$ In.29050, head in full-face view.

Рис. 2. Самки Lasius позднеэоценовых янтарей. L. schiefferdeckeri (1-2): экз. GZG.BST N 04188, общий вид инклюза сверху (1) и снизу (2). Lasius pumilus (3): экз. GZG.BST N 04099, общий вид инклюза. Lasius punctulatus : 4 - неотип, ПИН N 964/475, общий вид инклюза; 5 - эк3. ВMNH N In.29050. голова сверху.

rounded. Ocelli big, forming obtuse triangle. Eyes oval, large and convex. Length of gena ca. 1.5 times more than maximum width of scape. Scape somewhat longer than head, surpassing occipital margin. First funicular segment subequal to second or third ones. Structure of masticatory margin of mandible variable. In most of specimens preapical cleft more or less well developed, while in some absent. Basal angle of mandible either angled, or rounded. Maxillary palp 6-segmented, long. Dorsal surface of scutum feebly convex, scutum strongly curved down anteriorly, but not overhanging pronotum. Propodeum (seen in profile) weakly convex. Petiolar scale high and thick; seen in pro- 
file, its anterior surface feebly convex, posterior one straight, and crest of scale rounded; length of petiole twice less than height. Legs long and slender. Stipites of genitalia triangular, pointed at the apex. Body densely but not coarsely punctated, of somewhat shiny appearance. In the specimen GZG.BST N 04193 standing hairs present only on clypeus, gastral sternites and genitalia, but in specimen GZG.BST N 04256 also present on frons (one pair), in ocellar area (one pair), on scutum (three pairs), and sparse hairs on gastral tergites, starting from second one. Head and mesosoma, except for mesopleura, with dense decumbent pilosity; pilosity on gastral tergites much sparser, length of appressed hairs at least twice bigger than distance between them. Wing venation as in gynes.

Measure ments (in millimetres). Workers: syntype GZG.BST N 04221: length of mesosoma 0.86 ; length of head without mandibles 0.86 ; length of scape 0.77 ; maximum diameter of eye 0.22 . Non-type specimens: length of mesosoma $0.63-1,39$ (mean $0.97 \pm 0.02, \mathrm{n}=64$ ); length of head without mandibles $0.53-1,04$ (mean $0.81 \pm 0.02$, $\mathrm{n}=32$ ); width of head $0.60-1,07$ (mean $0.80 \pm 0.02, \mathrm{n}=22$ ); length of scape $0.51-1,04$ (mean $0.76 \pm 0.02, \mathrm{n}=41$ ); maximum diameter of eye $0.15-0.29$ (mean $0.22 \pm 0.01, \mathrm{n}$ = 11). Gynes: length of mesosoma 1,0-2,05 (mean 1.52, $\mathrm{n}=5$ ); length of head without mandibles $0.875-1,1$ (mean $1.00, \mathrm{n}=4)$; width of head $0.8-0.9$ (mean $0.86, \mathrm{n}=$ 2 ); length of scape $0.85-1,0$ (mean $0.92, n=4)$; maximum diameter of eye $0.25-0.37$ (mean $0.30, \mathrm{n}=5$ ); length of forewing $4-5$ (mean $4.3, \mathrm{n}=3$ ). Male s: length of mesosoma $1,1-1,46$ (mean $1.28, \mathrm{n}=3$ ); length of head without mandibles $0.58-0.64$ (mean $0.61, \mathrm{n}=2$ ); length of scape $0.35-0.78$ (mean $0.56, \mathrm{n}=3$ ); maximum diameter of eye $0.28(\mathrm{n}=1)$; length of forewing $2,4-3,7$ (mean $2.9, \mathrm{n}=3$ ).

Taxonomic notes. L. schiefferdeckeri resembles modern L. alienus Förster and L. sitkaensis Pergande, but differs from them by the smaller average size and by the high level of variability.

This species was described by Mayr from the Baltic Amber based on 161 workers, 7 gynes and 6 males; only 11 workers from Mayr's type series are preserved nowadays: Naturhistorische Museum Wien N 1847/IX/19, 1847/IX/20. 1847/IX/21, 1984/31/188, 1984/31/188, 1984/31/189, 1984/31/190. 1984/31/191 (Ponomarenko, Schultz, 1988); GZG.BST N 04221 (3727-IV-75), 04222 (410-IV-55), 04223 (407-IV-54). The lectotype is not designated, and all these specimens should be considered as syntypes.

L. edentatus was described by Mayr (1868) based on the single male; the holotype is lost. Mayr noted only sole feature distinguishing this species from L. schiefferdeckeri: lack of teeth on the masticatory margin of mandible. Wheeler (1915) has not seen the holotype, and has not found any other specimens those fit Mayr's description. Wilson (1955) investigated three males of $L$. schiefferdeckeri, and found that the structure of their mandibles is very variable; as a result, he synonymised $L$. edentatus with $L$. schiefferdeckeri. I also noted the high variability of the structure of mandibles in males of L. schiefferdeckeri and confirm Wilson's synonymy.

Another species, L. punctulatus, was described by Mayr based on three gynes; the type material is also lost. Nevertheless, based on the original description, they differ from L. schiefferdeckeri by smaller size (3-3.8 $\mathrm{mm} v s$. $5 \mathrm{~mm}$ in L. schiefferdeckeri), and by presence of numerous standing hairs on the body. Wheeler (1915) has not seen Mayr's type specimens, but determined six gynes as L. punctulatus. Three of the latter, GZG.BST N 04178 (K4046), 04184 (K5079) and 04188 (K927) are preserved till now, and I investigated them. The body length of these thee gynes $(4-4.5 \mathrm{~mm})$ is less than that in L. schiefferdeckeri, given by Mayr ( $5 \mathrm{~mm})$, but bigger than in L. punctulatus (3-3.8 mm). By the all other features they are indistinguishable from $L$. schiefferdeckeri. Based on the latter, I suppose that Wheeler determined small gynes of L. schiefferdeckeri as L. punctulatus.

Yet Mayr (1868) drew attention to the high variability of the standing pilosity of workers of this species that is much higher than in modern Lasius species. Wilson (1955) also 
noted similarly high variability of the structure of mandible and relative length of scape in L. schiefferdeckeri. Furthermore, both mentioned authors could not find any discrete differences between specimens by any of the diagnostic features, and concluded that all of them belong to the same, while very variable species.

Our results confirm this conclusion. Thus, in the most hairy worker specimens (fig. 1, 4-7) standing hair present on clypeus (up to five pairs), on frons (up to five pairs), on ocellar area (up to 3 pairs), on occipital margin, pronotum, mesonotum and propodeum (up to five pair on each), on petiolar scale (up to four pairs), and on the whole surface of gastral tergites and sternites. On the contrary, some specimens possess standing hairs only on clypeus, two hairs on propodeum, and a few hairs along posterior margin of the first gastral tergite only (fig. 1,2).

The ratio scape length / head width of 11 specimens examined by Wilson vary from 0.87 to 1.21 . I found similar range of variability of this ratio $(0.85-1.29)$ based on much richer investigated material. At the same time, there are full set of intergradations between minimal and maximal values, and, similarly to preceding authors, I also cannot divide examined specimens into different species.

\section{Lasius pumilus Mayr, 1868}

Lasius pumilus Mayr, 1868: 46, tab. II, fig. 33 (worker), Baltic Amber, Late Eocene; Dalla Torre, 1893: 190; Andrŭ, 1895: 82; Handlirsch, 1907: 860; Wheeler, 1915: 122; Wilson, 1955: 57-59; Burnham, 1978: 114; Bolton, 1995: 225; Dlussky, 1997: 59.

Lasius pusillus: Wheeler, 1915: 142 (misspelling).

Lasius pumilis: Wilson, 1955: 57 (misspelling); as senior synonym of L. punctulatus Mayr, not confirmed (see below).

Material. Baltic Amber: neotype, MZ PAN N 20891 (worker, designated here). Non-type material: GZG.BST N 04212 ( $\alpha 189$ ) (worker, determined by Wheeler as L. pumilus), GZG.BST N 04818 (B11717) (worker, determined by Wheeler as Iridomyrmex goepperti), GZG.BST N 04018 и 04099 (gynes), MZ N 10358, 16320. 16818 (workers). Bitterfeldian Amber: HM N 16/236 (worker).

Redescription of worker (fig. 1, 8-9). Body length 1.25-1.75 mm. Head trapezoidal narrowed anteriorly, with rounded occipital corners and feebly convex occipital margin; its length distinctly more than width. Eyes oval, comparatively well developed, shifted somewhat posteriorly, so that length of gena subequal or slightly more than maximum diameter of eyes. Ocelli absent. Frontal triangle separated form rest of head by sutures. Frontal carinae short, subparallel. Clypeus (seen in profile) with transverse impression. Anterior clypeal margin (seen from above) smoothly rounded. Scape surpassing occipital margin. Funicular segments enlarged to the apex, but apical club not developed. Length of 2 nd to 4th funicular segments less than width, rarely equal to width. Masticatory margin of mandible with six teeth. Palp formula 6, 4. Maxillary palp long, reaching occipital foramen. Mesosoma with promesonotal and metanotal sutures; mesopleural suture absent. Dorsal surface of promesonotum (seen in profile) forming regular arch, promesonotal groove very weak. Propodeum (seen in profile) angled, its posterior (declivous) surface distinctly more than twice longer than dorsal one.s Petiolar scale (seen in front or from behind) narrow, with slightly convex sides and straight dorsal margin; its height more than width. Body quite coarsely punctated, but appears somewhat shiny. Decumbent hairs on gaster thin, hairs' length equal to or more than distance between them. Standing hairs present only on clypeus, on gastral sternites, and on tergites of gaster, starting from third one. Dorsum of mesosoma, scape, femora and tibiae without erect or suberect hairs.

First description of gyne (fig. 2, 3). Body length ca. $3.5 \mathrm{~mm}$. Head somewhat narrower than mesosoma, trapezoidal, narrowed anteriorly, with rounded occipital corners and straight occipital margin; its length 1.1-1.2 times more than width. Eyes of moderate size, shifted somewhat posteriorly; length of gena more than maximum diameter of eyes. Clypeus (seen in profile) evenly convex. Scape surpassing occipital margin. 
Length of second funicular segment subequal to its width subsequent segment longer than width. Scutum curved down anteriorly, not overhanging pronotum. Propodeum (seen in profile) more or less evenly rounded. Body finely punctated, appears shiny. Depressed pubescence in investigated specimen barely visible, but in any case it is not dense. Standing hairs present only on clypeus, on gastral tergites, starting from fourth one, and on all gastral sternites. Scape, femora and tibiae without erect or suberect hairs. Forewing with two closed radial $(1+2 \mathrm{r}$ and $3 \mathrm{r})$ cells. Radiomedial $(\mathrm{rm})$ and mediocubital (=discoidal) (mcu) cells absent. Vein sections 5RS and $4 \mathrm{M}$ with joint start (rs-m lost).

Measurements (in millimetres). Workers: neotype: length of mesosoma 0.59; length of head without mandibles 0.59 ; width of head 0.51 ; length of scape 0.48 ; length of petiole 0.13 ; height of petiole 0.21 . Non-type material: specimen HM N 16/236: length of mesosoma 0.52 ; length of scape 0.44 ; specimen GZG.BST N 04212: length of mesosoma 0.64. Gynes: specimen GZG.BST N 04018: length of mesosoma 1.29; length of head without mandibles 0.69; specimen GZG.BST N 04099: length of mesosoma 0.97; length of head without mandibles 0.67 ; length of scape 0.71 ; maximum diameter of eye 0.22 ; length of forewing 3.0.

Taxon omic notes. Workers of L. pumilus differ from almost all other fossil and modern Lasius species by the extremely small size. Only workers of extant North American $L$. sitiens Wilson are similarly small, but they have much shorter maxillary palp and strongly reduced, small eyes. Gynes of this species well differ from gynes of L. schiefferdeckeri and L. nemorivagus by the smaller size, and from L. punctulatus - by the absence of standing hairs on mesosoma, on the first and second gastral tergites, and on the most parts of the head.

The type specimens of $L$. pumilus are lost. Wheeler (1915) noted that he examined one Mayr's syntype, and 80 additional workers. Three of the latter were redescribed by Wilson (1955) and preserved in the Museum of Comparative Zoology of Harvard University (USA), in the collection of William A. Haren. In the collection GZG we found six workers, determined by Wheeler as L. pumilus. Three of them were included Wheeler $(1915$, p. 123$)$ in the list of investigated material [GZG.BST № 04177 ( $\alpha 203)$, GZG.BST № $04183(\alpha 190)$ and GZG.BST N $04212(\alpha 189)]$. I determined the specimen GZG.BST N 04212 as L. pumilus (body length $1.75 \mathrm{~mm}$, length of 2nd, 3rd and 4th funicular segments subequal to width), but I believe that two others are minor workers of $L$. schiefferdeckeri (body length more than $3 \mathrm{~mm}$, length of $2 \mathrm{nd}$, 3rd and 4th funicular segments more than width). Thee specimens from GZG.BST, originally determined by Wheeler as L. pumilus [Nos. $04501(\alpha 169), 04513$ ( $\alpha 251)$ и $04526(\alpha 208)$ ], are absent in the Wheeler's (1915) list of the examined material. The specimen GZG.BST № 04501 is the gyne of $L$. punctulatus, and two others are workers of $L$. schiefferdeckeri. Since Wheeler (1915) wrote that he had not seen gynes of L. pumilus, I may expect that this was based in the labeling error.

\section{Lasius nemorivagus Wheeler, 1915}

Lasius nemorivagus Wheeler, 1915: 123 (single gyne), Baltic Amber, Late Eocene; Wilson, 1955: 150; Burnham, 1978: 114; Bolton, 1995: 224; Dlussky, 1997: 59.

Redescription (based on Wheeler, 1915, with additions and alterations).

$\mathrm{G} y \mathrm{n}$ e. Body length $6 \mathrm{~mm}$. Head wider than mesosoma. Length of 2 nd to 6 th funicular segments less than width, 7th to 10th segments not longer than width. Maxillary palp long. Petiolar scale (seen in front or from behind) relatively wide, with straight (not concave) dorsal margin; seen in profile, it is thin. Body finely punctated, appears shiny. Head, mesosoma, gaster and coxae with sparse standing hairs.

Taxonomic notes. The holotype specimen (gyne) is lost. I did not find any material belonging to this species in the investigated material, so my opinion is based only on the brief Wheeler's description. According to original description, this species differs from 
gynes of other Lasius species from the Late Eocene ambers by the comparatively wide head that is wider than mesosoma, while in all other known species head is narrower than mesosoma

Lasius punctulatus Mayr, 1868, stat. rev.

Lasius punctulatus Mayr, 1868: 46, tab. II, fig. 34 (gyne); Dalla Torre, 1893: 190; Andrŭ, 1895: 82; Handlirsch, 1907: 861; Burnham, 1978: 114.

Lasius pumilis Mayr, 1868: (misspelling) synonymy by Wilson, 1955: 57; Bolton, 1995: 225; revived from synonymy: Dlussky, 1997: 59; confirmed here.

Material. Neotype (gyne, designated here), PIN N 964/475, Baltic Amber, Late Eocene. Non-type material: BMNH N In.29050 with the label "Presd. A. Thŭry, 1932. Lasius punctulatus Mayr, det. by C. Emery” (gyne); GZG.BST N 04501 (gyne), Baltic Amber, Late Eocene.

Redescription of gyne (fig.2, 4-5). Body length ca. 3.5-4.5 mm. Head somewhat narrower than mesosoma, trapezoidal, narrowed anteriorly, with rounded occipital corners and slightly convex occipital margin; it length only slightly more than width. Ocelli forming obtuse triangle. Eyes large, oval, slightly convex, shifted somewhat posteriorly; gena nearly as long as maximum diameter of eyes. Clypeus (seen in profile) evenly convex, its anterior margin (seen from above) smoothly convex. Scape surpassing occipital margin. 3rd and 4th funicular segments longer than width. Shape of the second segment variable: on right antenna of the neotype specimen it longer than width, but on left antenna - equal to width; in specimen BMNH № In. 29050 length of this segment in both antennae more than width. Palp formula 6, 4. Maxillary palp long, reaching occipital foramen. Dorsal surface of scutum and scutellum flat, forming a single straight line with only weak impression in suture. Scutum curved down anteriorly, but not overhanging pronotum. Propodeum (seen in profile) angled, its dorsal surface very short, nearly 3 times shorter than posterior (declivous) one; these surfaces meet at a rounded obtuse angle. Petiolar scale (seen in profile) with flattened dorsal crest; its dorsal margin (seen in front or from behind) distinctly notched. Body quite densely punctated, but appears shiny. Head and gastral tergites with dense decumbent pubescence; length of appressed hairs on head at least twice bigger than distance between them, hairs on gastral tergites several times bigger than distance between them. Decumbent pubescence on mesosoma is invisible in all examined specimens, but it does not mean that it is absent. Dorsal surface of head and occipital margin, as well as pronotum, scutum and all gastral tergites with rather abundant standing hairs. Scape, femora and tibia in the neotype and specimen BMNH N In.29050 without erect and suberect hairs; in the specimen GZG.BST N 04501 scape with very short suberect hairs, and fore femora with a row of some hairs on inner surface. Forewing with two radial $(1+2 \mathrm{r}$ and $3 \mathrm{r})$ and mediocubital (= discoidal) (mcu) closed cells. Radiomedial ( $\mathrm{rm}$ ) cell absent. Mediocubital cell small. Vein sections 5RS and $4 \mathrm{M}$ with joint start (rs-m lost).

Measure ments (in millimetres). Neotype: length of mesosoma 1.09; length of head without mandibles 0.75 ; length of scape 0.67 ; maximum diameter of eye 0.24 ; length of forewing 2.9. Specimen GZG.BST N 04501: length of mesosoma 1.6; length of head without mandibles 0.82; specimen BMNH N In. 29050: length of mesosoma 1.1; length of head without mandibles 0.83 ; width of head 0.75 ; length of scape 0.83 ; length of forewing 3.75 .

Taxonomic notes. Mayr (1868) described this species based on three gynes; all type specimens are lost. Based on the original description, L. punctulatus differs from $L$. schiefferdeckeri by the smaller body size (3-3.8 $\mathrm{mm}$ vs., $5 \mathrm{~mm}$ in L. schiefferdeckeri) and by the abundant standing hairs on a body. Despite the relatively small body size, Mayr excluded the possibility that these may be gynes of $L$. pumilus, since the length of their 2nd to 4th funicular segments more than width. Wilson (1955) ignored this Mayr's opinion and, despite he had not seen any specimens of $L$. punctulatus, he considered this name 


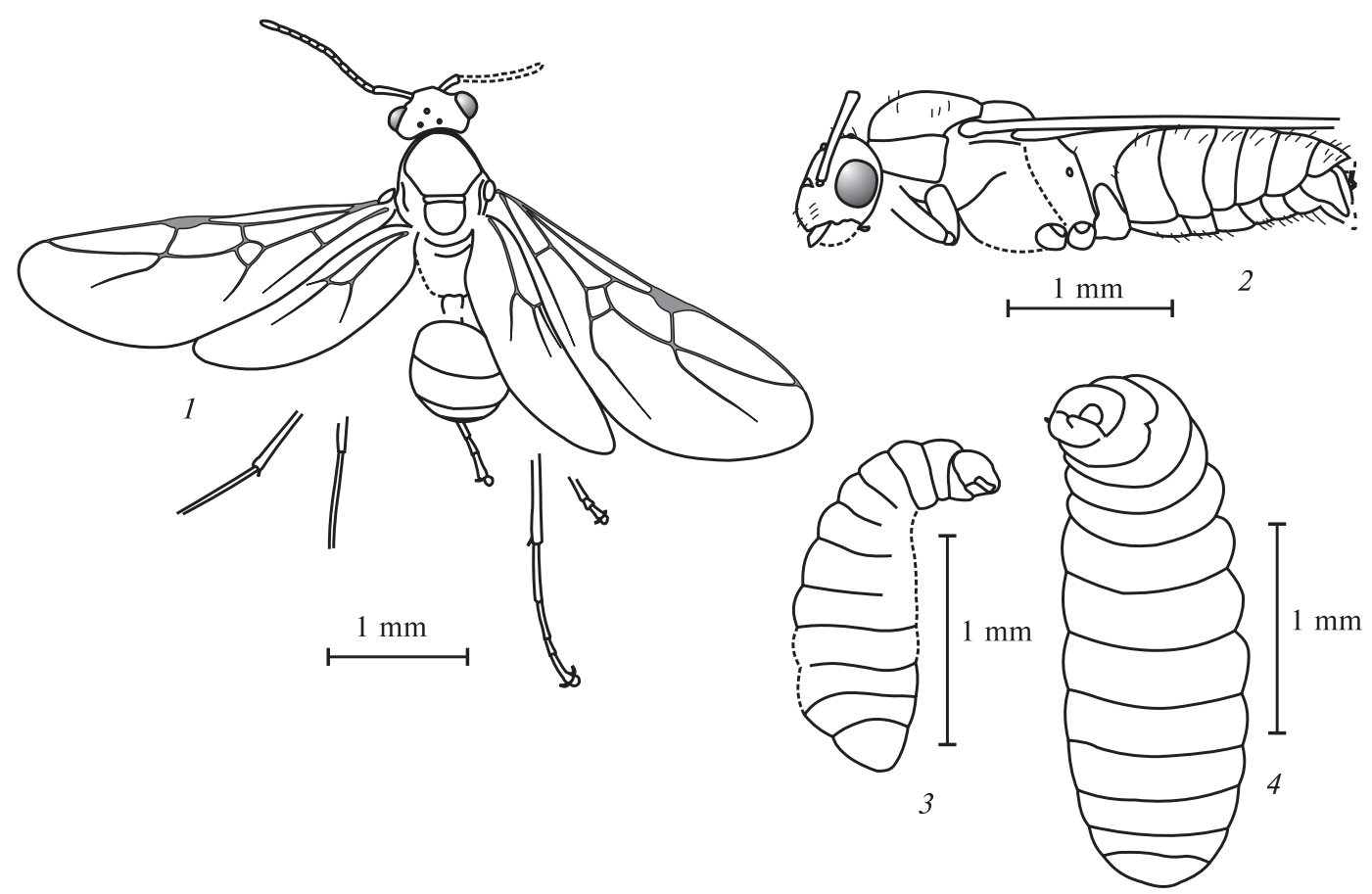

Fig. 3. Males $(1,2)$ and larvae (3, 4) of Lasius schiefferdeckeri. 1 - ex. GZG.BST (MKC) N 27.015, general view of the inclusion; $2-$ ex. SIZK N K-5331, general view of the inclusion; 3 - small larva, ex. GZG.BST (MKC) N 27.152b, general view of the inclusion; 4 - large larva, ex. GZG.BST (MKC) $\mathrm{N} 27.156$, general view of the inclusion.

Рис. 3. Самцы $(1,2)$ и личинки $(3,4)$ Lasius schiefferdeckeri. 1 - экз. GZG.BST (MKC) N 27.015, общий вид инклюза; 2 - экз. ИЗШК N K-5331, общий вид инклюза; 3 - мелкая личинка, экз. GZG.BST (MKC) N 27.152b, общий вид инклюза; 4 - крупная личинка, экз. GZG.BST (MKC) № 27.156.

as a junior synonym of $L$. pumilus, based only on the small size of the first species. To my opinion, the most important diagnostic feature, distinguishing $L$. punctulatus from $L$. pumilus, while ignored by Wilson, is the much more abundant standing pilosity on the body of the first species. Thus, I believe that Wilson's synonymy is erroneous and confirm reviving this name from synonymy. At last, as mentioned above, Wheeler had not seen Mayr's type specimens of L. punctulatus, and determined small gynes of L. punctulatus as L. schiefferdeckeri.

I found in Gottingen collection the gyne (GZG.BST.04501 ( $\alpha 169)$, having label "Lasius pumilus, Wheeler det." Nevertheless, I determined it as L. punctulatus: both dense appressed pubescence and abundant standing hairs well separate this specimen from $L$. pumilus that almost lacks standing hairs. Moreover, Wheeler (1915) wrote that he had not seen gynes of L. pumilus.

Key for the identification of Lasius species from the Late Eocene European ambers (workers and gynes) ${ }^{2}$ Таблица для определения видов рода Lasius из позднеэоценовых янтарей Европы (рабочие и самки)

1. Workers

- Gynes

2 (1). Body length $1.25-1.75 \mathrm{~mm}$. Standing hairs present only on clypeus, on gastral tergites, starting from third or fourth ones, and on all gastral sternites. Length of 2nd to 4th funicular segments less than width (fig. $1,8)$ L. pumilus Mayr

- $\quad$ Body length 2.5-4.2 $\mathrm{mm}$. As a rule, at least sparse standing hairs present on dorsal surface of mesosoma and on all gastral tergites (fig. 1, 1, 2, 4). Length of 2nd to 4th funicular segments more than width (fig. 1, $1,2,6)$. L. schiefferdeckeri Mayr

3 (1). Head wider than mesosoma. Length of 2nd to 6th funicular segments less than width. Head, mesosoma, gaster and coxae with sparse standing hairs. Body length ca. $6 \mathrm{~mm}$ L. nemorivagus Wheeler 


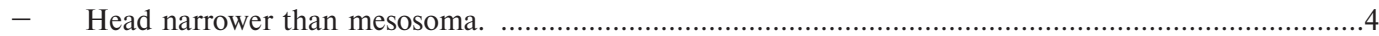

4 (3). Whole body with abundant standing hairs. Forewing with closed cell mcu (fig. 2, 4, 5). Body length 3.5-4.5 $\mathrm{mm}$.................................................................................................. L. punctulatus Mayr

- Head, except for clypeus, and mesosoma either without or with sparse standing hairs. ......................5

5 (4). Body length ca. $3.5 \mathrm{~mm}$. Forewing without closed cell $\mathrm{mcu}$ (fig. 2, 3). Length of 2nd to 4th funicular segments highly variable, it is either more or less than width. L. pumilus Mayr

- $\quad$ Body length 4-6 mm. Forewing with closed cell mcu (fig. 2, 1). Length of 2nd to 4th funicular segments always more than length. L. schiefferdeckeri Mayr

\section{Discussion}

The genus Lasius is divided to five subgenera: Lasius s. str., Cautolasius Wilson, 1955, Chthonolasius Ruzsky, 1912, Austrolasius Faber, 1967, and Dendrolasius Ruzsky, 1912. Members of the subgenus Lasius s. str. are herpetobionts or non-specialized dendrobionts. Body of workers is brownish or bicoloured, with reddish or brownish-yellow mesosoma and darker, usually dark brown to blackish head and gaster; they have well-developed eyes and long maxillary palp. Dendrolasius species are specialized dendrobionts and construct so-called carton nests in tree hollows. A characteristic feature of these ants is swollen occipital corners and usually strongly concave occipital margin of the workers, indicating an increasing of the muscles contraction mandibles. They are usually shiny black or dark brown, with well-developed eyes, and long maxillary palp. Members of other subgenera are typical geobionts, whole body of workers is yellowish, and they have minute eyes and short maxillary palp.

Fertile gynes of the subgenera Lasius and Cautolasius found new colonies independently, but those of other subgenera are temporary social parasites. Their gynes to found a new colony get into the nests of other species (Lasius s. str., while the Dendrolasius also into Chthonolasius), then kill a host queen and replace it.

L. schiefferdeckeri, L. pumilus and L. punctulatus with any doubt belong to the subgenus Lasius s. str. At the same time, L. schiefferdeckeri is much more variable morphologically than any known extant members of this subgenus. Major workers of the modern Lasius s. str. species [e. g. L. niger (Linnaeus), L. alienus (Förster), L. brunneus (Latreille), L. emarginatus (Olivier), etc.] at most 1.3-1.4 times bigger than minor ones; similar relation is also characterized for the subgenus Chthonolasius [e. g. L. umbratus (Nylander), L. meridionalis (Bondroit), L. mixtus (Nylander), etc.]. However, major workers of L. schiefferdeckeri twice bigger than minor ones, and by this feature they resemble L. (Cautolasius) flavus (Fabricius): this ratio in the latter species is 2.2.

The frequency distribution of $L$. schiefferdeckeri workers by size classes is close to normal (fig. 4, 1). The middle-sized workers with the length of mesosoma $0.85-1.05 \mathrm{~mm}$ accounted for a half of the studied specimens. The proportions of this species are also quite variable, but a weak monophasic allometry presents. In the presence of allometry, head of the major workers is relatively wider and scape is relatively shorter than that of minor ones; there is an inverse correlation between the size of the workers and the values of the cephalic index (CI, the ratio of the length of head to width) and scape index (SI, the ratio of the length of scape to the head length). I found a quite low but statistically significant inverse correlation between the length of mesosoma and CI $(\mathrm{r}=$ $-0.70 . \mathrm{n}=6, \mathrm{P}=0.05)$ and between the length of head and SI $(\mathrm{r}=-0.461, \mathrm{n}=24$, $0.02>\mathrm{P}>0.01$ ) (fig. 4, 2) in the measured workers of L. schiefferdeckeri.

Based on the fact that head of $L$. nemorivagus is wider than mesosoma, Wheeler (1915) supposed its relation with the modern L. (Chthonolasius) umbratus. Despite Wilson (1955) did not see neither the type specimens, nor any other material of L. nemorivagus, he accepted Wheeler's treatment and placed this species in the subgenus Chthonolasius.

\footnotetext{
${ }^{1}$ Workers of L. nemorivagus and L. punctulatus are unknown. Males are known only in L. schiefferdeckeri.
} 


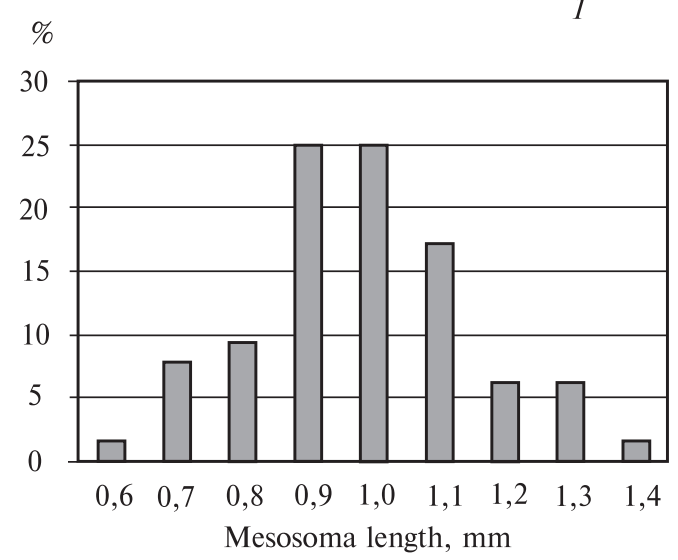

SI

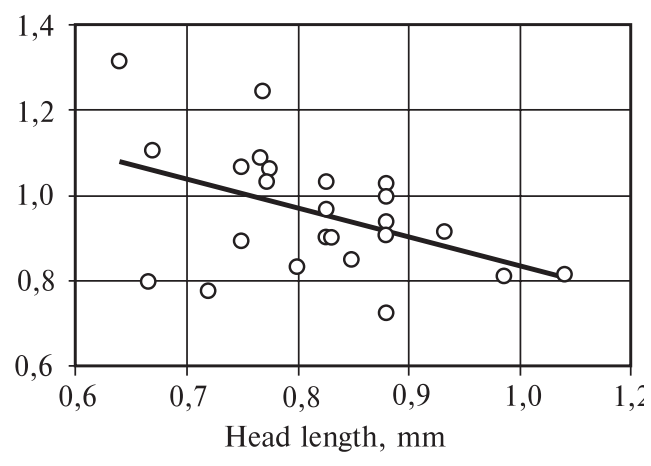

Fig. 4. Frequency distribution of mesosoma length values (1) and dependency of SI (scape length/head length) from values of head length (2) among workers of Lasius schiefferdeckeri.

Рис. 4. Частотное распределение по размерным классам длины мезосомы (а) и связь между длиной головы и индексом скапуса (SI - отношение длины скапуса к длине головы) (б) у рабочих Lasius schiefferdeckeri.

Indeed, head in gynes of the modern subgenera Lasius s. str. and Cautolasius is narrower than mesosoma, while in those of Chthonolasius and Dendrolasius it is wider than mesosoma. The average body size of gynes of Lasius s. str. and L. (Cautolasius) flavus is 2.0-2.4 times more than those of conspecific workers, while gynes of Chthonolasius and $L$. (Dendrolasius) fuliginosus are only 1.3-1.8 times bigger than workers. Undoubtedly, this is due to the different character of formation of new colonies. Queens of Lasius s. str. and Cautolasius before hatching of first workers feeding larvae by feed eggs and by secretions of the glands, lysing wing muscles and body fat. That is why these gynes have comparatively large, heavy abdomen, and they need to have well-developed wing musculature. As a result, their mesosoma is wide and robust. At the same time, gynes of Chthonolasius and Dendrolasius are temporary social parasites and their first larvae are fed by host workers. Accordingly, these gynes have smaller size, not so big gaster and a relatively narrow mesosoma.

Nevertheless, to my opinion, placing L. nemorivagus into subgenus Chthonolasius based solely on the relation of the width of head and mesosoma is incorrect. Species of this subgenus have short maxillary palp, whereas those of L. nemorivagus are long, si-milarly to all known species of the subgenus Lasius s. str. It is very likely that gynes of at least some extinct members of this subgenus were not so well adapted to the independent founding of new colonies, and their mesosoma was much narrower than in mo-dern species. This idea can be also supported by relatively small body size of queens of $L$. schiefferdeckeri compare with workers (they are ca. 1.8 times bigger than workers). This hypothesis was discussed earlier in conformity with Lasius vetulus Dlussky (Длусский, 1981): width of head in gynes of this species subequal to width of mesosoma.

The absence of Cautolasius, Chthonolasius and Austrolasius species in Late Eocene ambers not makes any surprise. All members of these subgenera are geobionts and their workers very rarely walking up on tree trunks; consequently, they have a very low chance to be trapped in resin and subsequently fossilize in amber. On the other hand, the absence of Dendrolasius species in ambers is quite noteworthy, as all members of this subgenus are dendrobionts and should be trapped in resin. Consequently, it is quite logic to suppose that they were absent in Late Eocene European "amber" forests. They were not also found in the sediment deposits of the Middle Eocene (Messel, Eckfeld, Germany; Bembridge, England) and Late Oligocene (Rott, Germany), of the Middle Miocene (Vishnevaia balka, Stavropolsky Krai, Russia, etc.) and of the Pliocene of Europe. Most 
probably, only one species, Lasius inflatus (Zhang) described from Miocene sediments of China (Shanwang), belongs to the subgenus Dendrolasius.

The genus Dendrolasius contains six extant species distributed exclusively in the Palaearctic and only one of them, L. fuliginosus, is known from Europe, Caucasus, West Siberia and northern Kazakhstan 3 ; all other species distributed in the Russian Far East, north-eastern China, Korean peninsula, and Japan (Radchenko, 2005; see also Murayama, 2006 ). Based on the mentioned above, one may with high probability suppose that subgenus Dendrolasius originated in the Eastern Palaearctic, and L. fuliginosus permeated to Europe not long ago in geological time.

L. schiefferdeckeri is one of the commonest ant species in the Late Eocene European ambers, the second one subsequent to Ctenobethylus goepperti (Mayr). Thus, in the amber collections examined by me, its specimens comprise (from the total number of ants, determined to species): Baltic Amber - 15.2-19.5\%, Bitterfeldian Amber - 24.5\%, Rovno Amber - 23.8\%, and Scandinavian Amber - 23.6\%. To comparison, ratios of C. goepperti specimens in the same ambers were: $52.1-50.3 \%, 42.3 \%, 37.8 \%$, and $25.8 \%$, respectively. Workers of $L$. schiefferdeckeri consist $96.7 \%$, gynes $-1.6 \%$, and males $1.7 \%$ of inclusions. Similar ratios are characteristic for most herpetobiont and dendrobiont ants.

19 pieces of amber included L. schiefferdeckeri together with other ant species: Aphaenogaster sommerfeldti Mayr (1), Bradoponera meieri Mayr (1), Camponotus mengei Mayr (1), Ctenobethylus goepperti (Mayr) (11), Formica flori (Mayr) (2), Myrmica intermedia Wheeler (1), Oecophylla brischkei Mayr (1) and Procerapachys annosus Wheeler (1 piece). Wheeler (1915) also recorded finding of this species with Cataglyphoides constrictus (Mayr). These data evidenced that these species not only lived in the same period, but occurred in the same sites.

$70(8.9 \%)$ of 714 examined by me pieces of amber with L. schiefferdeckeri contain from two to 17 specimens (mean - 3.01); such pieces contain $22.8 \%$ of all found specimens of this species. I recorded similar ratios for C. goepperti too: $9.5 \%$ (161 from 1700 pieces) contain more than one worker (mean 3.21), and these pieces contain $25.1 \%$ of all found specimens.

It is evident from these data that ants often moved by groups, trekking on trees to aphid's colonies, as many modern ant species. This suggestion is supported by finding of numerous syninclusions of these two species and aphids, mostly with Germaphis dryoides (Germar et Berendt) (Перковский, 2007, 2008).

Five examined pieces of amber contain workers of $L$. schiefferdeckeri with their larvae (fig. 3, 3, 4) or pupae, most probably carried by workers. Ants carry brood when they remove to another nest, or when they exchange brood between nests in polycalic colonies. As ants, trapped in resin, walked mostly on trees, one may suppose that nests of L. schiefferdeckeri were at least occasionally on trees. Unlike $C$. goepperti, whose workers have clear morphological adaptations to arboreal style of life (e. g. strong mandibles with blunt teeth; shape of the head indicating a well development of mandibular muscles; short antennae and legs that does not hinder movement in the narrow holes in tree branches or trunk, etc.), workers of L. schiefferdeckeri have no similar morphological adaptations to the arboreal style of life. The latter species is a typical representative of the subgenus Lasius s. str. All modern species of this subgenus build nests in a soil or in a strongly decayed, soft wood. Consequently, one may suppose that L. schiefferdeckeri built nests under a bark, in decayed parts of living trees (e.g. hollows, died branches, etc.), or in epiphytes.

2 Stärke (1942) described Lasius (Dendrolasius) buccatus based on gynes and males from Bosnia and Herzegovina (Dragocaj-Sarajevo); since that time any new material belonging to this species was not found. To my opinion, this name should be junior synonym of the common in Europe L. fuliginosus (see also Radchenko, 2005). 
I sincerely grateful to A. G. Radchenko (SIZK) for the help with English translation of the paper and for valuable comments ad discussion, and to A. P. Rasnitsyn (PIN). E. E. Perkovsky (SIZK), R. Kulicka (MZ PAN), A. Ross (BMNH), M. Reich (GZG), and M. Kutscher (Sassnitz, Rugen, Germany) for the giving opportunity to examined and described various amber collections. This work was supported by grants RFFI (N 08-04-00701 and 11-04-00421), and Forschungsgemeinschaft (DFG, German Research Foundation) (grant № RUS $17 / 17 / 07)$.

Dlussky, G. M. Miocene ants (Hymenoptera, Formicidae) of the USSR // New fossil insects from the territory of the USSR / V. N.Vishniakova., G. M. Dlussky, L. N. Pritykina - Moscow : Nauka Press, $1981-$ P. 64-83. - Russian : Длусский Г. М. Миоценовые муравьи (Hymenoptera, Formicidae) CCCP // Новые ископаемые насекомые с территории СССР / В. Н.Вишнякова, Г. М. Длусский. Л. Н. Притыкина

Dlussky G. V. Genera of ants (Hymenoptera: Formicidae) of Baltic Amber // Paleontol. Journal. — 1997. N 6. - P. 50-62. - Russian : Длусский Г. М. Роды муравьев (Нymenoptera: Formicidae) балтийского янтаря.

Dlussky G.M., Perkovsky E.E. Ants (Hymenoptera, Formicidae ) from the Rovno Amber // Vestnik zoologii. 2002. - 36. - N 5. - P. 3-20. - Russian : Длусский Г. М., Перковский Е. Э. Муравьи ровенского янтаря.

Perkovsky E.E. Syninclusions of Ants Lasius schiefferdeckeri (Hymenoptera, Formicidae ) and Aphids Germaraphis (Homoptera, Aphidinae) in Rovno and Saxonian Ambers // Vestnik zoologii. — 2007. 41. - N 2. - P. 181-185. - Russian : Перковский Е. Э. Сининклюзы муравьев Lasius schiefferdeckeri (Hymenoptera, Formicidae) и тлей рода Germaraphis (Homoptera, Aphidinae) в ровенском и саксонском янтарях .

Perkovsky E.E. First Finding of Syninclusion of Ants Lasius schiefferdeckeri (Hymenoptera, Formicidae ) and Aphids Germaraphis (Homoptera, Aphidinae) in Baltic Amber // Vestnik zoologii. - 2008. - 42. - N 2. - P. 180.- Russian : Перковский E. Э. Первая находка сининклюза муравьев Lasius schiefferdeckeri (Hymenoptera, Formicidae) и тлей рода Germaraphis (Homoptera, Aphidinae) в балтийском янтаре.

André E. Notice sur les fourmis fossiles de l'ambre de la Baltique et description de deux espuces nouvelles // Bull. Soc. Zool. France. - 1895. - 20. - P. 80-84.

Bolton B. A new general catalogue of the ants of the World. - London : Harvard University Press, 1995. $504 \mathrm{p}$.

Bolton B., Alpert G., Ward P. S., Naskrecki P. Bolton's Catalogue of ants of the world. Cambridge, Mass : Harvard University Press, 2006. - (CD version.)

Burnham L. Survey of social insects in the fossil records // Psyche. - 1978. - 89. - P. 85-133.

Cockerell, T. D. A. British fossil insects // Proc. U. S. Natl. Mus. - 1915. - 49. - P. 469-499.

Cockerell, T. D. A. Fossil insects from the Miocene of Colorado // Ann. Mag. Nat. Hist. - 1927. - 9, N 19. P. 161-166.

Dalla Torre C. G. Catalogus Hymenopterarum, hucusque descriptorum systematicus et synonymicus. Lipsiae. - 1893. - 7. - 289 p.

Donisthorpe, H. British Oligocene ants // Ann. Mag. Nat. Hist. - 1920. - 9, N 6. - P. 81-94.

Emery C. Hymenoptera. Fam. Formicidae. Subfam. Formicinae // Genera Insectorum. - 1925. - 183. - 302 p.

Handlirsch A. Die fossilen Insekten und die Phylogenie der rezenten Formen. Ein Handbuch für Paläontologen und Zoologen. Lieferung 6. - Leipzig: Wilhelm Engelmann, 1907. - P. 801-960.

Heer $O$. Die Insektenfauna der Tertiärgebilde von Oeningen und von Radoboj in Croatien. Zweiter Theil: Heuschrecken, Florfliegen, Aderflüger, Schmetterlinge und Fliegen. - Leipzig : W. Engelmann, 1849. - 264 S.

Heer O. Fossile Hymenopteren aus Oeningen und Radoboj // Neue Denkschr. Allg. Schweiz. Ges. Gesammten Naturwiss. - 1867. - 22. - S. 1-42.

Mayr G. L. Vorläufige Studien über die Radoboj-Formiciden, in der Sammlung der geologischen Reichsanstalt // Jahrb. Geol. Reichsan., Wien. - 1867. - 17. - S 47-62.

Mayr G. L. Die Ameisen des Baltischen Bernstein // Beitr. Naturkund. Preuss. Königsberg. - 1868. - 1. S. $1-102$.

Murayama M. A new synonymy in the subgenus Dendrolasius of the genus Lasius (Hymenoptera, Formicinae) // Bull. Natn. Sci. Mus. Ser. A. - 2006. - 31, N 3. - P. 115-117.

Ponomarenko A. G., Schultz O. Typen der Geologisch-Paläontologischen Abteilung: Fossile Insekten // Kataloge wissentschaft. Samml. Naturhist. Mus. Wien. Paläozoologie. - 1988. - 6, N 1. - S. 1-30.

Radchenko A. A review of the ants of the genus Lasius Fabricius, 1804, subgenus Dendrolasius Ruzsky, 1912 (Hymenoptera: Formicidae) from East Palaearctic // Ann. Zool. - 2005. - 55, N 1. - P. 83-94.

Wheeler W. M. The ants of the Baltic Amber // Schrift. Phys.-ökon. Ges., Königsberg. - 1915. - 55. - S. 1-142. Wilson E. O. A monographic revision of the ant genus Lasius // Bull. Mus. Compar. Zool., Harvard. - 1955. 3, N 1. - P. 1-200. 